\title{
IDENTIFICATION AND TYPING OF Haemophilus influenzae IN IRAQI CHILDREN DIAGNOSED WITH MENINGITIS
}

\section{ABDULHASAN G.A. ${ }^{1}$, SABBAH M.A..$^{2}$, JASEM K.A. ${ }^{3}$ AND HASSANI H.H. ${ }^{1}$}

${ }^{1}$ Biology Department, College of Science, Baghdad, Iraq.

2Biotechnology Research Center, Alnahrain University, Habna, Baghdad, Iraq.

${ }^{3}$ Ministry of Health, Central Health Laboratory, Baghdad, Iraq.

${ }^{*}$ Corresponding Author: Email- majeedbio@gmail.com

Received: April 06, 2013; Accepted: April 22, 2013

\begin{abstract}
Meningitis is the major cause of morbidity and mortality among infants and children below the age of five years. Meningitis might be caused by infection with viruses, bacteria, fungi or parasites. Haemophilus influenzae represents one of the causing agents of meningitis in children. During 2010, 400 Cerebrospinal fluid (CSF) specimens were collected from children less than 5 years, which clinically diagnosed with meningitis, in several hospitals of Iraq. Microbiological, biochemical and PCR techniques were used for identification and typing of Haemophilus influenzae isolates. Culturing CSF specimens revealed that $11(2.75 \%)$ isolates belonging to genus Haemophilus then these isolates were more identified as $\mathrm{H}$. influenzae according to the biochemical properties. According to the biotyping assay, it was found that $55 \%$ of $H$. influenzae isolates were identified as biotype I, $18.2 \%$ biotyped as V and VII for each one, and $9 \%$ biotyped as II, whereas all isolates (100\%) identified as serotype $b$ using slide agglutination test. PCR analysis was used for detection of $H$. influenzae in 75 specimens of cultured and noncultured CSF which divided into four groups (confirmed, probable, suspected, and control) according to the clinical and laboratory criteria of meningitis. Three genes, ompP6, bexA, and bcs3, were selected to verify the existence of $H$. influenzae type $b$ using triplex PCR. It was found that $23(30.7 \%)$ of $24 \mathrm{H}$. influenzae were belonged to $\mathrm{H}$. influenzae type $\mathrm{b} ; 11(14.7 \%)$ were culture positive -PCR positive while 12 (16\%) were culture negative -PCR positive, and only $1(1.3 \%)$ had noncapsulated properties for $\mathrm{H}$. influenzae. Moreover, $5(6 \%)$ of $23 \mathrm{H}$. influenzae type $b$ were detected as capsule deficient mutants which had ability to cause meningitis. Furthermore, according to capsular genotypes, hcs $A$, was indicated that $H$. influenzae type $b$ was distributed in two types, I and II, type I was predominant $(78.3 \%)$ in children under 5 years old whereas type II infected only $5(21.7 \%)$ children less than 1year old. In conclusions, according to this study $\mathrm{H}$. influenzae serotype b and biotype I was the most common types among children less than 5 years old diagnosed as meningitis in Iraqi children. $H$. influenzae can be identified directly from CSF by using different types of PCR techniques based on the amplification of cap genes which showed high sensitivity and specificity comparing with culture method.
\end{abstract}

Keywords- Haemophilus influenzae, PCR, meningitis

Citation: Abdulhasan G.A., et al. (2013) Identification and Typing of Haemophilus influenzae in Iraqi Children Diagnosed with Meningitis. International Journal of Microbiology Research, ISSN: 0975-5276 \& E-ISSN: 0975-9174, Volume 5, Issue 3, pp.- 417-423. DOI : 10.9735/09755276.5.3.417-423.

Copyright: Copyright@2013 Abdulhasan G.A., et al. This is an open-access article distributed under the terms of the Creative Commons Attribution License, which permits unrestricted use, distribution and reproduction in any medium, provided the original author and source are credited.

\section{Introduction}

Meningitis is an inflammation of the protective membranes covering the brain and spinal cord that known as meninges. It is the major cause of morbidity and mortality among infants and children less than the age of 5 years [1]. Meningitis might be caused by infection with viruses, bacteria, fungi, parasite, and less commonly by certain drugs. Viral meningitis (aseptic meningitis) was responsible for 82$94 \%$ of acute meningitis and resolve spontaneously whereas bacterial meningitis (BM) with $6-18 \%$ was sometimes fatal and frequently associated with severe neurological sequelae [2]. BM was responsible for most infections affected CNS. From all the cases occurred in children $H$. influenzae, Neisseria meningitides, and streptococcus pneumoniae were the pathogen responsible for $80-90 \%$ of the cases where as group B streptococci, Escherichia coli K1, and Listeria monocytogenes were the most causative agents in neonatal. Staph- ylococcus aureus, Pseudomonas aeruginosa, and Mycobacterium tuberculosis are less frequent of BM [3].

The role of $H$. influenzae as the major pathogen in meningitis was evidenced in many studies in developing countries that it was the most frequents organism isolated from CSF cultures $[4,5]$ while in United State, it was the fourth isolated agent due to massive vaccination programmed [6].

H. influenzae exists in two forms capsulated (a-f) and non capsulated [7]. Type b capsular strains are associated with invasive disease which is estimated by world health organization (WHO) in 2005 to cause three million cases of meningitis and severe pneumonia and 386000 deaths worldwide per year in children aged less than 5 years old [8]. These cases primarily occurred in developing countries where the disease was not readily recognized, antibiotic treatment was scarce and a vaccine was not available [9]. 
Identification of $H$. influenzae by traditional methods is difficult to establish for several reasons because culturing is time consuming, requires viable bacteria, and effecting by antibiotic treatment before spinal tap result in negative culture in about $30 \%$ of cases [3] as well as the residual human blood that sometimes used in preparing chocolate agar media might contain antibiotic and antibodies which effect growth of bacteria [10]. Latex agglutination test have a lower sensitivity and specificity that requires high concentration of bacteria $\left(10^{6} \mathrm{CFU} / \mathrm{ml}\right)$ for positive result and might showed misreading of serotyping results [11].

Rapid techniques based on nucleic acid amplification such as PCR have been reported to be more sensitive and specific for detection of $\mathrm{H}$. influenzae compared to bacterial culture and slide agglutination test [12-14]. Capsular genes were suitable target for the detection and typing of capsulated $H$. influenzae by using PCR assay and different target genes within capsular locus have been described [15-17].

Identification of the causative agent for meningitis is important for diagnosis, treatment and vaccine development, so the aim of this work was to elucidate the involvement of $H$. influenzae type in meningitis diagnosed in Iraqi children less than five years old.

\section{Materials and Methods}

\section{CSF Specimens Collection}

Four hundred CSF specimens were collected from infants and children aged from one month to five years during period from first January to first December 2010, in different hospitals in Iraq. Each child was underwent lumber puncture as part of their diagnostic evaluation.

Three to five milliliter of CSF was collected in to two sterile tubes that were used for cytological, chemical that analyzed at once, and microbiological examinations. The specimens were delivered to the central health laboratory with ice bag and kept at $-20^{\circ} \mathrm{C}$ until processed or transferred in $\mathrm{T}-\mathrm{I}$ medium that left at room temperature for at least one month.

\section{Identification of Bacteria}

Chocolate and GC media (supplemented with $2 \%$ haemoglobin and $1 \%$ isovitalex (Mast group, UK) for $X$ and $V$ factors) were inoculated with loopfull of CSF or $100 \mu$ l from T-I media then incubated at $37^{\circ} \mathrm{C}$ for 24-48 hours under aerobic condition with $10 \% \mathrm{CO}_{2}$. Suspected colonies were identified morphologically by Gram stain. Oxidase and API-NH system (Bio-Mereix, France) used according to manufacture instructions for the diagnosis and biotyping of Haemophilus. $H$. influenzae was biotyped on the bases of indol production, urease and ornithine decarboxylase activity [18] as well as the nutritional requirements of $H$. influenzae to both $X$ and $V$ factors were tested on Mueller-Hinton agar.

All isolates were serotyped by slide agglutination test with type specific antisera from a-f (BD BBL, Mast group, UK) according to manufacture instructions for detecting the serotype of capsulated $H$. influenzae isolates.

\section{Extraction of Genomic DNA}

DNA was extracted from $H$. influenzae isolates using a commercial purification system (wizard genomic DNA purification kit, promega, USA) following the manufacturers instruction for DNA purification from gram negative bacteria. While the DNA was extracted from $100 \mu l$ CSF using three methods includes: Genomic DNA Mini Kit
(Geneaid, Thailand), Wizard Genomic DNA Purification Kit (Promega, USA) used according to manufacture instructions, and boiling method that DNA was extracted from CSF by incubating of specimen for $10 \mathrm{~min}$ at $95^{\circ} \mathrm{C}$, followed by centrifugation at 13000 rpm for $1 \mathrm{~min}$, the supernatant was transferred to a clean microfuge tube and stored in deep freezer until PCR analysis is carried out [19].

The DNA concentration and purity were determined by using spectrophotometer; DNA quality could be assessed by $0.8 \%$ agarose gel electrophoresis [15].

\section{PCR Assay}

PCR was done in Triplex and duplex to amplify different fragments of genes under study for detecting $H$. influenzae and capsular associated genes.

Triplex PCR was used to amplify three genes including [Table-1]: OmpP6 that found in both capsulated and non-capsulated $H$. influenza, BexA (capsular gene) was used to distinguish between capsulated and nonencapsulated strains, and Bcs3 Cap region II type $b$ specific gene was used to determine type $b$ specific capsule. The last two genes were used to detect type $b$ deficient mutant and distinguished it from non-capsulated.

Two primer sets were used in duplex PCR to amplify hcsA for determining genotypes I and II that belongs to type $b$.

\section{PCR Amplification}

The extracted DNA, primers and PCR premix (Accupower, Bionear), was thawed at $4^{\circ} \mathrm{C}$, vortex and centrifuged briefly to bring the contents to the bottom of the tubes. PCR mixture was set up in a total volume of $20 \mu$ lincluded $5 \mu$ l of PCR premix, $1 \mu$ l of each primer $(2$ picomole/ $\mu \mathrm{l})$ and $2 \mu \mathrm{l}$ of template DNA (250 $\mathrm{ng} / \mu \mathrm{l})$ have been used. The rest volume was completed with sterile D.W. PCR mixture was performed according to the number of tests and distributed into PCR reaction tubes with $18 \mu \mathrm{l}$, vortexed and finally $2 \mu \mathrm{l}$ of template DNA was added. Negative control contained all material except that D.W was added instead of template DNA [Table-1].

Table 1- The primers and their sequences used in conventional $P C R$ for detection of $H$. influnzae

\begin{tabular}{|c|c|c|c|c|}
\hline Gene & $\begin{array}{l}\text { Primer } \\
\text { Name }\end{array}$ & Sequence $5^{\prime} \rightarrow 3^{\prime}$ & $\begin{array}{l}\text { PCR Product } \\
\text { Size }\end{array}$ & Reference \\
\hline $\mathrm{ompP}_{6}$ & HIIV F & ACTTTTGGCGGTTACTCTGT & & \multirow{2}{*}{$\begin{array}{l}\text { VanKetal et } \\
\text { al. } 1990\end{array}$} \\
\hline $\mathrm{ompP}_{6}$ & HI-V R & TGTGCCTAATTTACCAGCAT & & \\
\hline bexA & $\mathrm{HI}-1 \mathrm{~F}$ & CGTTTGTATGATGTTGATCCAGAC & \multirow{2}{*}{343 bp } & \multirow{2}{*}{$\begin{array}{l}\text { VanKetal et } \\
\text { al. } 1990\end{array}$} \\
\hline bexA & $\mathrm{HI}-2 \mathrm{R}$ & TGTCCATGTCTTCAAAATGATG & & \\
\hline bcs3 & b1 F & GCGAAAGTGAACTCTTATCTCTC & \multirow{2}{*}{$480 \mathrm{bp}$} & \multirow{2}{*}{$\begin{array}{l}\text { Falla et al. } \\
\text { (1994) }\end{array}$} \\
\hline bcs3 & b2 R & GCTTACGCTTCTATCTCGGTGAA & & \\
\hline hcsA & hcs A F-I & GTACTTGTCATTGACCAAACTTT & \multirow{2}{*}{$450 \mathrm{bp}$} & \multirow{2}{*}{$\begin{array}{l}\text { Scholus et } \\
\text { al. } 2008\end{array}$} \\
\hline hcsA & hcs A R-I & GGTATATTGAAAGTATGCTGCAT & & \\
\hline hcsA & hcs A F-II & TGCTTGTCATCGATCAAA & \multirow{2}{*}{$817 \mathrm{bp}$} & \multirow{2}{*}{$\begin{array}{l}\text { Scholus et } \\
\text { al. } 2008\end{array}$} \\
\hline hcsA & hos AR-\| & ACTAAAGAAAGGGGTGCAA & & \\
\hline
\end{tabular}

Amplification was conducted using a mastercycler (Eppendorf) programmed with 1 cycle at $95^{\circ} \mathrm{C}$ for $5 \mathrm{~min}, 40$ cycles of $95^{\circ} \mathrm{C}$ for 1 $\min , 58^{\circ} \mathrm{C}$ for $1 \mathrm{~min}, 72^{\circ} \mathrm{C}$ for $1 \mathrm{~min}, 72^{\circ} \mathrm{C}$ for $10 \mathrm{~min}$. The amplified product was subjected to $1.5 \%$ agarose gel electrophoresis, and visualized under UV after ethidium bromide staining.

\section{Determination of PCR Specificity (20)}

The DNA from some bacteria that caused meningitis including Escherichia coli, Enterobacter cloacae, Klebsiella pneumoniae, 
Streptococcus pneumoniae, Staphylococcus aureus, and H. influenzae were extracted. The concentration and purity of DNA from each one was determined then analyzed by PCR and the results confirmed by using $1.5 \%$ agarose gel electrophoresis.

\section{Statistical Analysis}

Data were presented as percentage and/or mean \pm standard error. The Statistical Analysis System-SAS (2004) was used to analyse the effect of difference factors in this study. The Chi-square $\left(X^{2}\right)$ test was employed for the analysis of meanwhile least significant differences (LSD) test was adopted to analyse percentages. T-test was used to analyse other data. $P$ value $\leq 0.05$ was considered statistically significant (21).

\section{Results}

\section{Isolation and Identification of Heamophilus influenzae from} Culturing CSF Specimens

Over all specimens, 11 (2.75\%) have characteristics of Haemophilus influenzae. According to the biotyping assay, four biotypes of $H$. influenzae were observed depending on three tests included indol, urease, and ornithine decarboxylase by using API-NH system. Six of isolates $(55 \%)$ represented biotype I, while $18.2 \%$ of isolates were equally distributed in biotype V and biotype VII, and low percentage $(9 \%)$ of isolates showed properties of biotype II. whereas all isolates (100\%) identified as serotype b using slide agglutination test.

\section{DNA Extraction from $\boldsymbol{H}$. influenzae isolates and CSF specimens}

DNA from all isolates of $H$. influenzae type b was successfully extracted by using Wizard genomic DNA purification kit (Promega, USA), DNA bands were confirmed and analyzed by gel electrophoresis while column based commertial kit (Genaid, Tailand) was more efficient the other methods had been used as illustrated in [Fig-1].

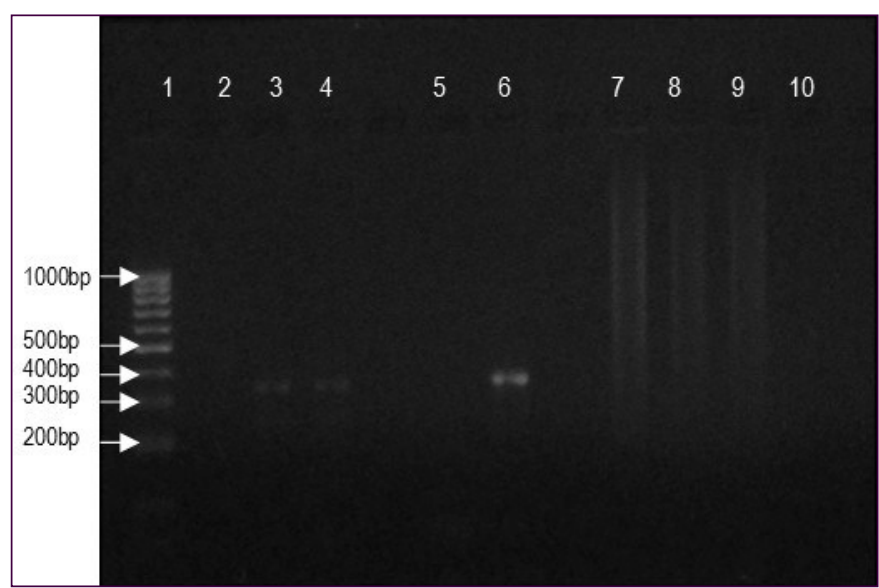

Fig. 1- Gel electrophoresis of amplified bexA (343bp) in H. influenzae from CSF specimens, using different methods for DNA extraction. Agarose (1.5\%), $5 \mathrm{~V} / \mathrm{cm}$ for $2 \mathrm{hrs}$, stained with ethidum bromide and visualized on a UV transilluminator. Lane 1. 100 bp DNA ladder. Lane 2. PCR done by using CSF specimens directly without DNA extraction. Lane 3-4. PCR products of extracted DNA from CSF using boiling method. Lane 5-6. PCR product of extracted DNA from CSF using boiling method (line 5) and Genied kit (line 6) for the same specimens. Lane 7-9. PCR product of extracted DNA from CSF using Promega kit. Lane 10. Negative control (had all PCR mixture including water instead of DNA template).

\section{Detection of $\boldsymbol{H}$. influenzae Type b by Triplex PCR}

Triplex PCR was used to verify the existence of $H$. influenzae type $b$ in 75 specimens from cultured and noncultured CSF. For this purpose, three genes (ompP6, bexA and bcs3) with their primers were selected. The results revealed distinct amplicon patterns for type $b$ $\mathrm{b}+$, and non capsulated $H$. influenzae [Fig-2] and [Fig-3].

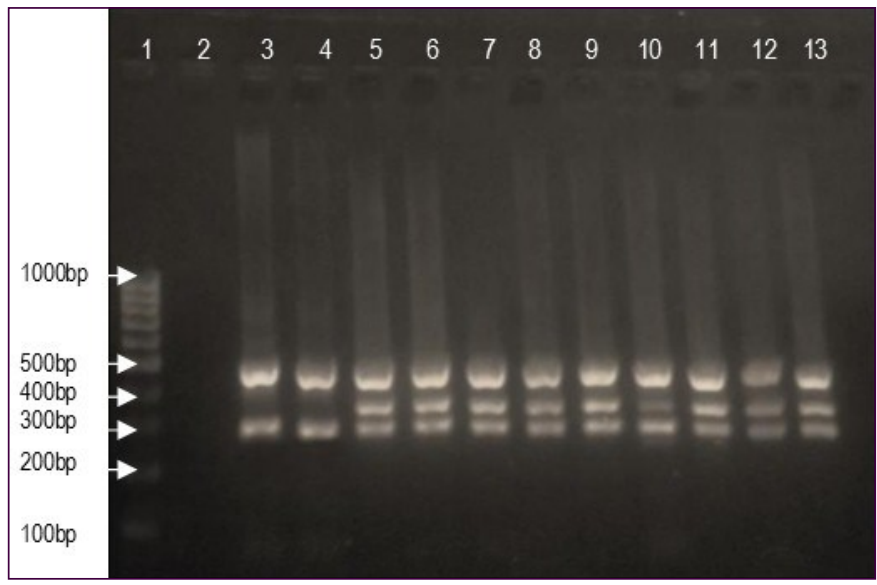

Fig. 2- Gel electrophoresis of amplified ompP6 (273pb), bexA (343bp) and bcs3 (480bp) amplified from $H$. influenzae DNA of cultured CSF using multiplex PCR. Agarose 1.5\%, $5 \mathrm{~V} / \mathrm{cm}$ for $2 \mathrm{hrs}$, stained with ethidum bromide and visualized on a UV transilluminator. Lane 1. 100 bp DNA ladder. Lane 2. Negative control (had all PCR mixture including water instead of DNA template). Lane 3-4. Deficient mutant of type $\mathrm{b}$ capsule which had bcs3 but not bexA. Lane 5-13. Type b capsule.

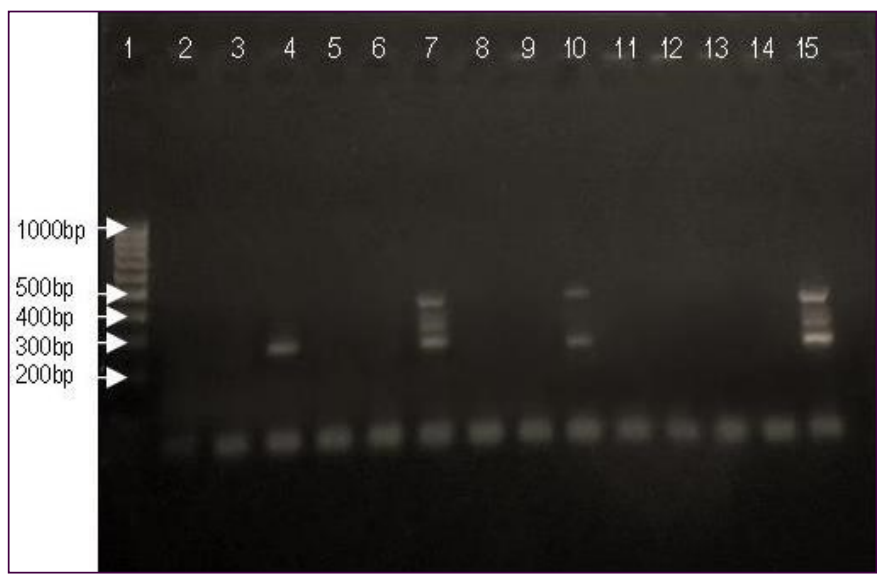

Fig. 3- Gel electrophoresis of amplified ompP6 (273pb), bexA (343bp) and bcs3 (480bp) amplified from DNA of CSF specimens using multiplex PCR. Agarose 1.5\%, $5 \mathrm{~V} / \mathrm{cm}$ for $2 \mathrm{hrs}$, stained with ethidum bromide and visualized on a UV transilluminator. Lane 1. 100 bp DNA ladder. Lane 2. Negative control (had all PCR mixture including water instead of DNA template). Lane 3,5,6,8,9,11-14. Negative CSF specimens. Lane 4. Noncapsulated $H$. influenzae. Lane 7,15 . Type $b$ capsule. Lane 10 . Deficient mutant of type $b$ capsule which had bcs3 but not bexA .

On the basis of data listed in [Table-2], [24] (32\%) of 75 cultured and noncultured CSF were belonged to $H$. influenzae according to conventional PCR results. $23(30.7 \%)$ of these $H$. influenzae were belonged to type $b$ and only 1 case $(1.3 \%)$ had noncapsulated properties of $H$. influenzae and failed to produce product with primers $\mathrm{HI}$ -I and $\mathrm{HI}-\mathrm{II}$ of bexA which is responsible for transport of capsule. 
Table 2- Amplification state of $\mathrm{H}$. influenzae from cultured and noncultured CSF specimens.

\begin{tabular}{lccccc|} 
Culture state & N=75 & ompP6 & bexA & bcs3 & Capsule phenotype \\
\hline CSF-Culture positive & 9 & + & + & + & $\mathrm{b}^{+}$ \\
$\mathrm{N}=11$ & 2 & + & - & + & $\mathrm{b}^{-}$ \\
CSF-Culture negative & 9 & + & + & + & $\mathrm{b}^{+}$ \\
$\mathrm{N}=13$ & 3 & + & - & + & $\mathrm{b}^{-}$ \\
CSF negative & 1 & + & - & - & Noncapsulated \\
\hline
\end{tabular}

On the other hand, $11(14.7 \%)$ of $23 \mathrm{H}$. influenzae type b showed culture positive-PCR positive results, while $12(16 \%) H$. influenzae type b showed culture negative-PCR positive results which $9(75 \%)$ of 12 had preadmission of antibiotic treatment.

Five $(6 \%)$ of $23 \mathrm{H}$. influenzae type b detected as $\mathrm{H}$. influenzae capsule deficient mutants type $b\left(b^{-}\right)$. These mutants failed to produce bexA with $343 \mathrm{bp}$ but could be clearly recognized from noncapsulated by producing type b specific product $480 \mathrm{bp}$. Two of isolates identified as capsule deficient mutants by using PCR capsular genotyping while in serotyping observed type b capsule.

Notably, 5 (38\%) of CSF culture negative-PCR positive results were successfully analyzed by PCR when delivered to the laboratory in $T$ -I medium which maintained bacteria at bad condition.

[Table-3] showed that the diagnostic specificity of culturing method was high (100\%) but the diagnostic sensitivity was low (46\%) when compared with PCR technique for diagnosis $H$. influenzae in CSF specimens.

Table 3- Comparison of culturing and PCR methods for detection $\mathrm{H}$. influenzae from CSF of meningitis cases.

\begin{tabular}{|cccccc} 
Culture & \multicolumn{2}{c}{ PCR } & Total & $\begin{array}{c}\text { Diagnostic } \\
\text { Sensitivity }\end{array}$ & $\begin{array}{c}\text { Diagnostic } \\
\text { Specificity }\end{array}$ \\
\hline+ & 11 & 0 & 11 & $46 \%$ & $100 \%$ \\
\hline & 13 & 51 & 64 & & \\
\hline
\end{tabular}

The results of all methods used in study demonstrated that the identification rate of $H$. influenzae culturing 75 samples was $14.7 \%$ (11 sample) whereas this rate had increased to $30.6 \%$ (23 samples) for $H$. influenzae type $b$ and $23 \%$ (24 samples) for $H$. influenzae when used PCR technique.

\section{Genotyping of $\boldsymbol{H}$. influenzae Type b by Duplex PCR}

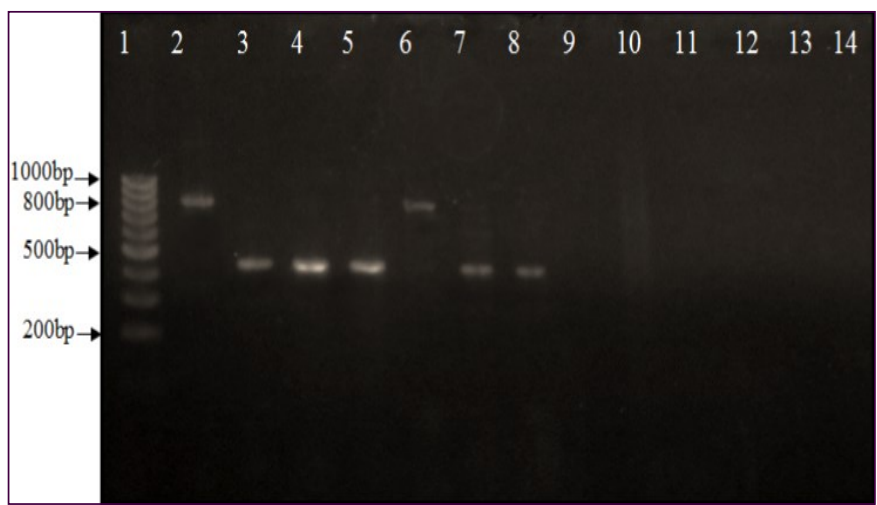

Fig. 4- Gel electrophoresis of amplified hcsA type I (450pb), and hcsA type II (817bp) from DNA of $H$. influenzae type $b$ isolates. Agarose 1.5\%, $5 \mathrm{~V} / \mathrm{cm}$ for $2 \mathrm{hrs}$, stained with ethidum bromide and visualized on a UV transilluminator. Lane 1. 100 bp DNA ladder. Lane 2 and 6 . Type II of $H$. influenzae type b. Lane 3-5, 7-8. Type I of $H$. influenzae type b. Lane 14. Negative control (had all PCR mixture including water instead of DNAtemplate).
The prevalence of type I and II in $H$. influenzae type b capsule was done by using two sets of primer for hcsA. A distinct amplicon patterns were noticed as previously shown in [Fig-4]. In addition, the distribution of capsular genotypes I and II among 23 cultured and noncultured CSF specimens illustrated in [Table-4].

The results indicated that type I was predominant it account $78.3 \%$ and distributed in children under four years old whereas type II formed $21.3 \%$ and appeared only in children less than one year old yielding a statistically significant difference $(p \leq 0.01)$.

The specificity of selected primers appeared to be highly specific for $H$. influenzae since there was no DNA amplified from other bacteria used in this study.

Table 4- Distribution of capsular genotypes I and II among H. influenzae type $b$ according to age groups

\begin{tabular}{|c|c|c|c|c|}
\hline \multirow{2}{*}{$\begin{array}{l}\text { Age groups } \\
\text { (months) }\end{array}$} & \multirow{2}{*}{ No. of $\mathrm{Hib}^{*}$} & \multicolumn{2}{|c|}{ Capsule locus Type (\%) } & \multirow{2}{*}{$x^{2}$ Value } \\
\hline & & Type I & Type II & \\
\hline$>12$ & 13 & $\begin{array}{c}8 \\
(62)\end{array}$ & $\begin{array}{c}5 \\
(38)\end{array}$ & $6.755^{* *}$ \\
\hline |12-24 & 4 & $\begin{array}{c}4 \\
(100)\end{array}$ & $\begin{array}{l}0 \\
(0)\end{array}$ & 12.50 ** \\
\hline $25-36$ & 2 & $\begin{array}{c}2 \\
(100)\end{array}$ & $\begin{array}{c}0 \\
(0)\end{array}$ & $12.50^{* *}$ \\
\hline $37-48$ & 4 & $\begin{array}{c}4 \\
(100)\end{array}$ & $\begin{array}{c}0 \\
(0)\end{array}$ & 12.50 ** \\
\hline 49-60 & 0 & $\begin{array}{c}0 \\
(0)\end{array}$ & $\begin{array}{c}0 \\
(0)\end{array}$ & $0.00 \mathrm{NS}$ \\
\hline Total & 23 & $\begin{array}{c}18 \\
(78.3)\end{array}$ & $\begin{array}{c}5 \\
(21.7) \\
\end{array}$ & - \\
\hline
\end{tabular}

*Hib: H. influenzae type $b$.; ${ }^{* *} P \leq 0.01$, NS non significant.

\section{Discussion}

Meningitis caused by $H$. influenzae serotype $b$ is an important human disease worldwide especially in children less than five years old. Hence, it's important that early diagnosis improves clinical outcomes [22].

This study showed isolation rate $2.75 \%$. Studies from different parts of the world described various isolation rates of $H$. influenzae as reported by Peltola [23] that $13.8 \%$ isolates in Iraq between 19881989. In Iran, it was $15.7 \%$ [24] but in another study it was $31.4 \%$ [25] while in Nepal, the isolation rate was $1.7 \%$ [8]. MacNeil et al. [2 [6found that isolation rate of $H$. influenzae in United States was $5.4 \%$

The different isolation rates may be due to inadequate microbiological methods, the effect of prior antibiotic used or genetic differences in patients and/or $H$. influenzae type $b$ strains [8]. On the other hand, there was reduction in isolation rates of $H$. influenzae type $b$ meningitis after vaccination which noted in several European countries, Canada and United States [27].

The isolates of this study were biotypes I, V, VII, and II in decreasing order of frequency. In previous studies from Denmark, Norway, Western Europe and United State had been shown that biotype I account for most of $H$. influenzae meningitis that might approach to $96 \%$ and it was predominant in children under ten years old [32]. In contrast, in Papua New Guinea and Vietnam indicated that biotype II account for $62-68 \%$ of $H$. influenzae meningitis [28].

Surprisingly, biotypes $\mathrm{V}$ and VII were found recently to be responsible for meningitis that was believed the invasive strains expressing capsular type would belong only to biotypes I, II, and III. One case with biotype $V$ serotype $b$ was first found caused meningitis in Brazil [29]. From studying more recent invasive noncapsulated $H$. influen- 
zae isolates appeared strong association to biotype $\mathrm{V}$ with the presence of IS1016, and showed unusually resistant to killing by normal human serum [15].

Moreover, four biotypes found in this study were also showed indol positive reaction indicated that tryptophanase was important in virulence; Martin et al., [30] found that $94-100 \%$ among strains of $H$. influenzae had tryptophanase are causing serious disease including meningitis.

Based on serotyping results, all isolates belonged to serotype b. These results were expected and as stated by shoma et al. [13] and Lancellotti et al. [31] that other serotypes not detected in CSF of children less than five years of age, suggesting that $H$. influenzae type $b$ is the primary cause of invasive infections such as meningitis.

This study also presented to optimize PCR assay for direct identification and typing of $H$. influenzae.

The final choice from three methods used to estimate their efficacy for isolation DNA from CSF specimens depended on the comparison of PCR results which exhibited a distinct band with the specific molecular weight; this reflects the ability of method for removing PCR inhibitors and producing purified DNA. Therefore, a commercial kit (Geneaid, Tiland) for extraction DNA from CSF and amplified it was more efficient than the other methods had been used. Indeed, this result was agreed with Shoma et al. [32] and Nakhjavani et al. [1] who showed that DNA extraction by a commercial kit might increase the yield of DNA sufficiently for PCR amplification.

The failure of boiling method for extraction DNA or using CSF directly without DNA extraction might returned to the presence of inhibitors that resulting in false negative [33]. Whereas wizard genomic DNA purification kit produced poor yield of DNA template, this could be due to low volume of CSF available, insufficient lysis of cell and/or loss of DNA during purification [34].

Three genes were used for identification of $H$. influenzae, the selected primers appeared to be highly specific for $H$. influenzae since there was no DNA amplified from other bacteria. This finding was agreed with earlier studies [35,36].

Triplex PCR was used to verify the existence of $H$. influenzae type $b$ in 75 specimens from cultured and noncultured CSF. The results proved the accuracy of the molecular techniques especially in negative culture specimens that 13 cases had culture negative-PCR positive results. This may return to a variety of factors including suboptimal storage or delay in delivering the specimens to the laboratory or to early administration of antibiotic prior to specimens collection. WHO (2002) confirmed that $50 \%$ of CSF cultures were positive for $H$. influenzae in children without prior treatment of antibiotic in comparison with children who treated prior spinal tap.

Several studies had been used these sets of primers and reported a good results on amplification of associated capsular genes in capsulated $H$. influenzae and differentiated from non capsulated and capsule deficient mutant of type b capsule [37-39]. From data above, Triplex PCR technique was a rapid and useful tool for detecting $H$. influenzae particularly in negative culture results due to high sensitivity compared to culture method (46\%). Many investigators reported the high sensitivity of this technique when used for detection of $H$. influenzae [13,40-42].

Five cases of capsule deficient mutant of type b capsule were recorded in this study in children less than one year old except one case aged two years old, similarly first noted by Catlin [43] who found CSF from child aged 30 months with meningitis contained a heterogenous population of $H$. influenzae (capsulated and noncapsulated). As well as another recently studied by Satola et al. [15] identified $H$. influenzae mutant (b-) from infant (6 months old) and other child had 36 months old.

Other investigators demonstrated differences in the rate of capsule deficient mutant of type $b$; it ranging from $3 \%$ to $5 \%[44,12]$ and in a previous study it recorded $12.5 \%$ [16], whereas LaClarie et al. [45], did not detect type $b$ deficient mutants.

However, the early studies proved that the expression of $H$. influenzae type $b$ capsule was genetically unstable and occurred in both in vivo and in vitro. The instability was due to high frequency loss of $b$ capsule by homologous recombination in which the presence of the repeat IS1016 elements at each end of capsule loci being targets for this recombination [46].

Cerquetti et al. [47] reported that the presence of a thicker capsule on the cell surface of multicopy strains was an advantage survival in the blood stream, but is an disadvantage when other surface components involved in the direct interaction between bacteria and brain endothelial cells that a thicker capsule may interfere with this interaction. Thus, loss of capsule leads to an increased ability to adhere to and invade human epithelial cells [48].

Interestingly, despite differences in capsule production, both type $b$ and deficient mutant of type $b$ from cultured and noncultured CSF in this study were capable of producing sustained bacteremia and meningitis suggesting one copy of capsule was sufficient for virulence that was noted also in infant rats model [49]. This return to the ability of some deficient mutant strains to elaborate detectable amount of polyribosylribitol phosphate (PRP) distributed on the surface of bacteria isolated from child with meningitis, suggesting that elaboration of quantitatively or qualitatively altered amount of PRP might support the virulence of capsule deficient mutants because PRP capsule confers a greater virulence than any of other type specific polysaccharide [50].

Other possible virulence determinants of the $H$. influenzae include outer membrane proteins that associated with capsulated and non capsulated strains responsible for neonatal septicemia and LPS implicated in serum resistance to complement dependent bacteriocidal antibodies to LPS [7,51].

In this study, serotyping of two isolates of $H$. influenzae as serotype $\mathrm{b}$ by slide agglutination test appered as capsule deficient mutants by using PCR capsular genotyping. This might returned either to losing of capsule in vitro after several subcultures as mentioned early by Corn et al. [52] or these isolates have detectable amount of PRP on their surface that cross react with type b specific antisera and produce misleading results that was agreed with Kostyanev et al. [53] who showed that $71 \%$ of capsule deficient mutants cross reacted with at least one specific antisera.

Other reasons for misreading of sreotyping results might returned to technical practice, type of method used and/or antisera quality. Laboratory to laboratory differences appearing to be due to interpretation of a positive agglutination reaction between bacterial suspension and antisera as amplification of the agglutination reaction by using antibody coated latex particles that yield good results [12].

From the reading above, PCR capsular genotyping was more accurate and useful to distinguish different capsular serotypes and capsule deficient mutants as well as distinguished them from noncapsulated strains. 
In an assessment of type I and II of $H$. influenzae type $b$ in children had meningitis by using PCR found that most children under four years old had infected with genotype I of $H$. influenzae type $b$ and this agreed with most reports from various world regions that the largest proportion of type I. It was also noted that type I had a thinner, dense and compact capsular layer which twice much more capsular polysaccharide than type II [54]. Thus, producing higher amount of capsular polysaccharide by type I require higher amount of antibody titer to eliminate type I in comparison with type II which present only in children less than one year old as noticed in this study. This may due to lack of bacteriocidal activity against this bacterium in this age group [55] whereas predominance of type I in other groups under four years old indicated the presence of some anticapsular antibody in their blood that protect them from type II because it is less virulence but not from infection with type I $\mathrm{H}$. influenzae type $b$ isolates that was not detected in last group (4-5 years) because it have enough anticapsular antibody that protect them from infection [56].

\section{Conclusion}

It found that $H$. influenzae serotype $b$ and biotype I was the most common types among children below 5 years old. $H$. influenzae can be identified directly from CSF by using different types of PCR technique based on the amplification of cap genes which showed high sensitivity and specificity comparing with culture method.

\section{References}

[1] Nakhjavani F.A., Hashemi B., Kalani M.T., Kazemi D.B., Nouri D.K., Azadi D.N., Haghiashteiani M.T., Aligholi M., Erfani U., Abedini M. (2005) Medical Journal of the Islamic Republic of Iran, 19,181-184.

[2] Dubos F., Lammotte B., Bibi-Triki F., Moulin F., Raymond J., Gendrel D., Breat B., Chalumeau M. (2006) Arch. Dis. Child., 91, 647-650.

[3] Failace L., Wagner M., Cheskey M., Scalco R., Jobim L.F., (2005) Arq. Neuropsiquiatr., 63, 920-924.

[4] Al-Mazrou Y.Y., Al-Jeffri M.H., Al-Haggar S.H., Musa E.K., Mohamed O.M., Abdalla M.N. (2004) J. Trop. Pediatr., 50, 131136.

[5] Abdulrab A., Algobaty F., Salem A.K., Mohammed Y.A.K. (2010) Jpn. J. Infec. Dis., 63,128-131.

[6] Thigpen M.C., Whitney C.G., Messonnier N.E., Zell E.R., Lynfield R., Hadler J.L., Harrison L.H., Farley M.M., Reingold A., Bennett N.M., Craig A.S., Schaffner W., Thoma A., Lewis M.M., Scallan E., Schuchat A. (2011) N. Engl. J. Med., 364, 20162025

[7] Schweda E.K., Richards J.C., Hood D.W., Moxon E.R. (2007) Int. J. Med. Microbiol., 297, 297-306.

[8] Huong P.L., Thi N.T., Anh D., Huong T., Minth L., Canh T., Matsuok M., Kamachi K., Yamazaki T., Arakawa Y., Sasaki T. (2006) Jpn. J. Infect. Dis., 59, 111-116.

[9] Broker M. (2009) Jpn. J. Infec. Dis., 62, 87-92.

[10]Kennedy W.A., Purdy C.K., Le T., Kilgore P., Kim J.S., Anh D., Huong P.L., Dong B.Q., Tan D.M., Clemens J.D., War J.I. (2007) Epidemiol. Infect., 135, 1217-1226.

[11]Nelson K.L., Smith L.S. (2010) Diag. Microbiol. Infect. Dis., 66, 235-240.
[12]Shoma S., Rahman M., Yasmin M. (2001) J. Health. Popul. Nutr., 19, 268-274.

[13]LaClaire L.L., Tondella M., Beall D.S., Noble C.A., Raghunathan P.L., Rosenstein N.E., Popovic T. (2003) J. Clin. Microbiol., 41, 393-396.

[14]Satola S.W., Napier B., Farley M.M. (2008) Infect. Immun., 76, 5221-5227.

[15]Falla T.J., Crook D.W., Brophy L.N., Maskell D., Kroll J.S., Moxon E.R. (1994) J. Clin. Microbiol., 32, 2382-2386.

[16]Maaroufi Y., Bruyne J.D., Heymans C., Crokkaert F. (2007) J. Clin. Microbiol., 45, 2305-2308.

[17]Davis G.S., Sandstedt S.A., Patel M., Marrs C.F., Gilsdorf J.R., (2011) J. Clin. Microbiol., 49, 2594-2601.

[18]Ohkusu K., Nash K.A., Inderlied C.B. (2005) Clin. Infect., 11, 637-643.

[19]Van Ketal R.J., De Wever B., Van Alphen L. (1990) J. Med. Microbiol., 33, 271-276.

[20]Maniatis T., Fritsch E., Sambrook J. (1982) Molecular Cloning: a Laboratory Manual, Cold Spring Harbor Laboratory, NY.

[21]Mandel J. (1984) The Statistical Analysis of Experimental Data, NY, USA.

[22]Tunkel A.R., Scheld W.M. (1993) Clin. Microbiol. Rev., 6, 118136.

[23]Peltola H. (1999) Bulletin of the WHO, 77(11), 878-887.

[24]Haghiashteiani M.T., Mohammadi-Yeganeh S., Soroush S., Sadeghifard N., Sayadi S., Dabyri H., Abedini M. and Taherikalani M. (2008) Iranian J. Pupl. Health, 397, 52-58.

[25]Mojgani N., Rahbar M., Taqizadeh M., Ashtiani S., Mohammad M. (2011) Jpn. J. Infec. Dis., 64, 66-68.

[26]Shah A.S., Knoll M., Sharma P.R., Moisi J.C., Kulkarni, P., Lalitha M.K., Steinhoff M., Thomas K. (2009) Clin. Infect. Dis., 48(2), S123-S128.

[27]MacNeil J.R., Cohn A.C., Farley M., Mair R., Baumbach J., Bennett N., Gershman K., Harrison L.H., Lynfield R., Petit S., Reingold A., Schaffner W., Thomas A., Coronado F., Zell E.R., Mayer L.W., Messonnier N.E. (2011) Clin. Infect. Dis., 53, 12301236.

[28]Theodoridou M.N., Vasilopoulou V.A., Atsali E.E., Pangalis A.M., Mostrou G.J., Vassiliki P.S., Christos S.H. (2007) BMC Infect. Dis., 7, 101.

[29]Landgraf I.M., Vieira M.F. (1993) J. Clin. Microbiol., 31, 743745.

[30]Rowji R., Gromkova R., Leinonen R. and Koornhof H. (1989) J. Gen. Microbiol., 135, 2775-2782.

[31]Lancelloti M., Pace F., Stehling E.G., Villares M.C., Brocchi M., Silveira W. (2008) Braz. J. Infect. Dis., 12, 430-437.

[32]Martin K., Morlin G., Smith A., Nordyke A., Eisenstark A., Golomb M. (1998) J. Bacteriol., 180, 107-118.

[33]Lu J., Perng C., Lee S., Wan C. (2000) J. Clin. Microbiol., 38, 2076-2080.

[34]Smith K., Diggle M.A. and Clarke S.C. (2003) J. Clin. Microbiol., 41(6), 2440-2443. 
[35]Deshpande P.S., Kashyap R.S., Ramteke S., Nagdev K.J., Purohit H.J., Taori G.M., Daginawala H.F. (2007) CSF Research, 4, 10-17.

[36]Corless C.E., Guiver M., Borrow R., Edwards-Jones V., Fox A.J., Kaczmarski E.B. (2001) J. Clin. Microbiol., 39, 1553-1558.

[37]Van Ketal R.J., De Wever B., Van Alphen L. (1990) J. Med. Microbiol., 33, 271-276.

[38]Arosio M., Nozza F., Rizzi M., Ruggeri M., Casella P., Beretta G., Ragilo A. and Goglio A. (2008) New Microbiologica, 31, 343349.

[39]Mojgani N., Rahbar M., Taqizadeh M., Ashtiani S., Mohammad M. (2011) Jpn. J. Infec. Dis., 64, 66-68.

[40]Ghotaslou R., Farajnia S., Yeganeh F., Abdoli-Oskoue S., Ahangarzadeh R.M., Barzegar M. (2012) Acta. Med. Iran., 50, 192-196.

[41]Hong E., Barraud O., Bidet P., Bingen E., Blondiaux N., Bonacorsi S., Burucoa C., Carrer A., Fortineau N., Couetdic G., Courcol R., Garnier F., Hery-Arnaud G., Lanotte P., Le Bars H., Legrand-Quillien M.C., Lemée L., Mereghetti L., Millardet C., Minet J., Plouzeau-Jayle C., Pons J.L., Schneider J., Taha M.K. (2012) Clin. Lab., 58, 343-346.

[42]Catlin B.W. (1970) Amer. J. Dis. Child., 120, 203-210.

[43]Bokermann S., Zanella R.S., Lemos A.P., Andrade A.L. and Brandileone M.C. (2003) J. Clinical Microbiology, 41, 55465550.

[44]Falla T.J., Crook D.W., Brophy L.N., Maskell D., Kroll J.S., Moxon, E.R. (1994) J. Clin. Microbiol., 32, 2382-2386.

[45]LaClaire L.L., Tondella M., Beall D.S., Noble C.A., Raghunathan P.L., Rosenstein N.E., Popovic T. (2003) J. Clin. Microbiol., 41, 393-396.

[46]Roche R.J., Moxon E.R. (1995) Trends Microbiol., 3, 304-309.

[47]Ogilvie C., Omikunle A., Wang Y., Geme J.S., Rodriguez C.A., Adderson E.E. (2001) J. Infect Dis., 184, 144-149.

[48]Cerquetti M., Cardines R., Atti M.L., Giufre M., Bella A., Sofia T., Mastrantonio P., Slack M. (2005) J. Infect. Dis., 192, 819823.

[49]Ohkusu K., Nash K.A., Inderlied C.B. (2005) Clin. Infect., 11, 637-643.

[50]Sukupolvi-Petty S., Grass S. and Geme III J.W. (2006) J. Bacteriol., 188(11), 3870-3877.

[51]Zwahlen A., Winkelstein J.A. and Moxon E.R. (1983) Infect. Immun., 42(2), 708-715.

[52]Corn P.G., Anders J., Takala A.K., Kayty H. and Hoiseth S.K. (1993) J. Infect. Dis., 167(2), 356-364.

[53]Kostyanev T., Setchanova L., Ouzounova-Raykova S.V., Proevska Y., Mitov I. (2010) Journal of IMAB, 16, 66-68.

[54]Scholus L., Heide H., Witteveen S., Zomer B., Ende A., Burger M., Schot C. (2008) BMC Microbiol., 8, 35-46.

[55]Tunkel A.R., Scheld W.M. (1993) Clin. Microbiol. Rev., 6, 118136.

[56]Crook D.W., Hood D.W. (2006) Priciples and Practice of Clinical Bacteriology, 2nd ed., England, 247. 